\title{
UPAYA PENINGKATAN PENGETAHUAN TENTANG PEMANTAUAN GULA DARAH MANDIRI DI DESA AMPAH II WILAYAH KERJA PUSKESMAS AMPAH KABUPATEN BARITO TIMUR
}

\author{
Alfeus Manuntung ${ }^{1}$ \\ Jurusan Keperawatan, Poltekkes Kemenkes Palangka Raya, Indonesia \\ *email: alfeusmanuntung@gmail.com
}

\begin{abstract}
Diabetes Mellitus Type 2 is the most common endocrine disease and the most common form of diabetes. Type 2 Diabetes Mellitus requires independent medical treatment and management education to prevent acute complications and reduce the risk of long-term complications. Management of Type 2 Diabetes Mellitus in patients while being hospitalized is the responsibility of the health team. The number of sufferers of diabetes mellitus (DM) from year to year tends to increase, in 1995 the number of DM sufferers in the world according to WHO as many as 135 million people and is expected to continue to increase to 299 million people in 2025. The purpose of this community service activity is to increase knowledge about independent blood sugar monitoring in Ampah Village II The working area of Ampah Health Center, East Barito Regency. The target in this community service activity is people with Type 2 Diabetes Mellitus (diabetes) aged 52 to 72 years in the work area of the Ampah Health Center. The implementation of community service activities was carried out in November 2018. The place of implementation of this community service is in the village of Ampah II, the work area of the Ampah Health Center, East Barito Regency. Counseling in community service activities uses tools such as leaflets, laptops, LCDs, TOAs, and microphones.
\end{abstract}

Keyword : Blood sugar levels, diabetes mellitus, knowledge, monitoring

\begin{abstract}
ABSTRAK
Diabetes Melitus Tipe 2 merupakan penyakit endokrin yang paling umum dan bentuk diabetes yang paling umum. Diabetes Melitus Tipe 2 membutuhkan perawatan medis dan pendidikan pengelolaan mandiri untuk mencegah komplikasi akut dan menurunkan risiko komplikasi jangka panjang. Penanganan Diabetes Melitus Tipe 2 pada pasien waktu dirawat di rumah sakit merupakan tanggung jawab tim kesehatan. Jumlah penderita Diabetes Melitus (DM) dari tahun ke tahun cenderung meningkat, pada tahun 1995 jumlah penderita DM di dunia menurut WHO sebanyak 135 juta jiwa dan diperkirakan akan terus meningkat menjadi 299 juta jiwa pada tahun 2025. Tujuan kegiatan pengabdian masyarakat ini yaitu meningkatkan pengetahuan tentang pemantauan gula darah mandiri di Desa Ampah II Wilayah kerja Puskesmas Ampah Kabupaten Barito Timur. Sasaran dalam kegiatan pengabdian masyarakat ini adalah orang penderita Diabetes Melitus Tipe 2 (diabetesi) usia 52 s.d. 72 tahun di wilayah kerja Puskesmas Ampah. Pelaksanaan kegiatan pengabdian masyarakat ini dilaksanakan pada bulan November 2018. Tempat
\end{abstract}

1 | Edukasi Masyarakat Sehat Sejahtera (EMaSS) : Jurnal Pengabdian kepada Masyarakat Volume 2 No.1 Tahun 2020 
pelaksanaan pengabdian masyarakat ini yaitu di Desa Ampah II wilayah kerja Puskesmas Ampah, Kabupaten Barito Timur. Penyuluhan dalam kegiatan pengabdian masyarakat ini menggunakan alat bantu yaitu leaflet, laptop, LCD, TOA, dan mikrofon.

Kata kunci : Diabetes mellitus, kadar gula darah, pengetahuan, pemantauan

\section{PENDAHULUAN}

Diabetes Melitus Tipe 2 merupakan penyakit endokrin yang paling umum dan bentuk diabetes yang paling umum. Diabetes Melitus Tipe 2 membutuhkan perawatan medis dan pendidikan pengelolaan mandiri untuk mencegah komplikasi akut dan menurunkan risiko komplikasi jangka panjang (Manuntung, 2018). Penanganan Diabetes Melitus Tipe 2 pada pasien waktu dirawat di rumah sakit merupakan tanggung jawab tim kesehatan (Edberg,2016).

Namun setelah pasien dipulangkan, maka pasien dan keluarga harus dapat mengambil alih tanggung jawab tersebut dengan cara melakukan perawatan mandiri (self care) sehingga pasien dan keluarga dibekali pengetahuan dan keterampilan yang cukup untuk mencegah kemungkinan rawat ulang (rehospitalisasi) dengan kondisi yang lebih buruk (Carey, 2018).

Pada tahap awal penyakit ini, sebagian besar tanpa gejala yang khas, atau kadang-kadang diawali oleh "3P" polifagi (banyak makan), polidipsi (banyak minum) dan poliuri (banyak kencing). Namun masyarakat terutama yang di pedesaan sering kali tidak menyadari gejalagejala tersebut, sehingga pada saat terdiagnosis menderita kencing manis sudah stadium lanjut dan sangat kronis yang akhirnya susah dikontrol tanpa obat (Soegondo dkk, 2011).

Pada tahun 2010 jumlahnya 8,4 juta jiwa dan diperkirakan meningkat menjadi 21,3 juta jiwa pada tahun 2030. Menurut PERKENI, penanganan DM membutuhkan 4 (empat) pilar, yaitu terapi gizi medis, obat-obatan, olahraga, dan pendidikan kesehatan. Salah satu langkah yang dapat dilakukan perawat untuk pengelolaan diabetes secara mandiri yaitu memberikan pendidikan kesehatan pada pasien dengan tepat karena pemberian pendidikan kesehatan dapat meningkatkan kemandirian pasien sehingga pengelolaan diabetes dapat optimal (Perkeni, 2016).

\section{METODE}

Pengabdian masyarakat dilakukan di Desa Ampah II wilayah kerja Puskesmas Ampah, Kabupaten Barito Timur dengan jumlah responden 10 responden penderita Diabetes Melitus Tipe 2 (diabetesi) usia 52-72 tahun. Evaluasi kegiatan pengabdian masyarakat ini dilakukan sebanyak 2 kali yaitu pre dan post intervensi. Evaluasi pertama dilakukan dengan menyebarkan 2 | Edukasi Masyarakat Sehat Sejahtera (EMaSS) : Jurnal Pengabdian kepada Masyarakat Volume 2 No.1 Tahun 2020 
kuesioner tentang pengetahuan tentang pemantauan gula darah mandiri dilanjutkan dengan pengukuran kadar glukosa darah sewaktu. Evaluasi kedua dilakukan setelah intervensi keperawatan dalam pengabdian masyarakat (pendidikan kesehatan tentang pemantauan gula darah mandiri) yaitu dengan penyebaran kuesioner. Alat bantu saat penyuluhan kegiatan pengabdian masyarakat yaitu leaflet, laptop, LCD, TOA, dan mikrofon.

\section{HASIL DAN PEMBAHASAN}

Kegiatan pengabdian kepada masyarakat diikuti sebanyak 10 orang di Desa Ampah II wilayah kerja Puskesmas Ampah, Kabupaten Barito Timur. Sebelumnya dilakukan pretest dengan menyebarkan kuesioner dengan 8 pertanyaan tentang pemantauan gula darah mandiri. Hasil pretest menunjukkan sebanyak 5 orang $(50 \%)$ mendapatkan nilai $\geq 50$. Kegiatan selanjutnya yaitu penyuluhan kesehatan tentang pemantauan gula darah mandiri. Evaluasi kedua dilakukan setelah intervensi keperawatan dalam pengabdian masyarakat yaitu dengan penyebaran kuesioner dan pemeriksaan glukosa darah sewaktu. Hasil posttest menunjukkan sebanyak 100 orang (100\%) mendapatkan nilai $\geq 50$. Hasil pemeriksaan glukosa sewaktu menunjukkan sebanyak 5 orang $(50 \%)>200 \mathrm{mg} / \mathrm{dL}$, sedangkan 5 orang $(50 \%)<200 \mathrm{mg} / \mathrm{dL}$.

Pemantauan glukosa darah mandiri (PGDM) merupakan bagian penatalaksanaan Diabetes Melitus yang sangat penting karena dapat mencegah terjadinya komplikasi DM, baik bersifat akut ataupun kronis. Pelaksanaan PGDM membutuhkan motivasi dan pendidikan secara tepat karena dilakukan dalam jangka waktu yang lama (Subekti, 2016).

PGDM terutama dianjurkan bagi pasien dengan pengobatan insulin atau obat pemicu sekresi insulin. Pada pasien DM dianjurkan untuk melakukan pemeriksaan glukosa darah secara mandiri adalah 2 kali dalam seminggu. Dengan melakukan pemeriksaan glukosa darah secara mandiri dan teratur, maka pasien akan mengetahui dampak penatalaksanaan DM pada dirinya dan semakin memperkuat perilaku perawatan dirinya (Suyono, 2017).

\section{SIMPULAN}

Kesimpulan yang dapat diambil berdasarkan hasil pengabdian kepada masyarakat yang dikuti sebanyak 10 orang diabetesi di Desa Ampah II wilayah kerja Puskesmas Ampah, Kabupaten Barito Timur, hasil pretest menunjukkan sebanyak 5 orang (50\%) mendapatkan nilai 250. Hasil posttest menunjukkan sebanyak 100 orang (100\%) mendapatkan nilai $\geq 50$, hasil pemeriksaan glukosa sewaktu menunjukkan sebanyak 5 orang $(50 \%)>200 \mathrm{mg} / \mathrm{dL}$, sedangkan 5 3 | Edukasi Masyarakat Sehat Sejahtera (EMaSS) : Jurnal Pengabdian kepada Masyarakat Volume 2 No.1 Tahun 2020 
orang $(50 \%)<200 \mathrm{mg} / \mathrm{dL}$. penyuluhan ini menekankan pada pendidikan kesehatan dan keterampilan tentang pemantauan gula darah mandiri bagi penderita Diabetes Melitus Tipe 2.

\section{DAFTAR PUSTAKA}

Manuntung, Alfeus. (2018). Analisis Keyakinan Diri Pasien Diabetes Melitus Tipe 2 dalam Pengelolaan Diabetes Melitus.Jurnal Kesehatan Manarang Vol.3 No.1 Hal 31-37.at: http://jurnal.poltekkesmamuju.ac.id/index.php/m/article/view/32

Edberg, M. (2016). Buku Ajar Kesehatan Masyarakat Teori Sosial dan Perilaku.Jakarta:EGC.

Carey,Barbara. 2018. Pengkajian dan Penatalaksanaan Pasien Diabetes Melitus.Jakarta:EGC

Perkeni. (2016). Konsensus Pengelolaan Diabetes Melitus Tipe 2 di Indonesia.

Subekti.(2016). Pengertian Diabetes \& Penatalaksanan Diabetes Melitus Terpadu Edisi Ke 2. Jakarta:Balai Penerbit FKUI

Suyono, S. (2017). Kecenderungan peningkatan jumlah penyandang diabetes. Jakarta:EGC. 